\title{
小児副鼻腔 $\mathrm{X}$ 線診断の補遺

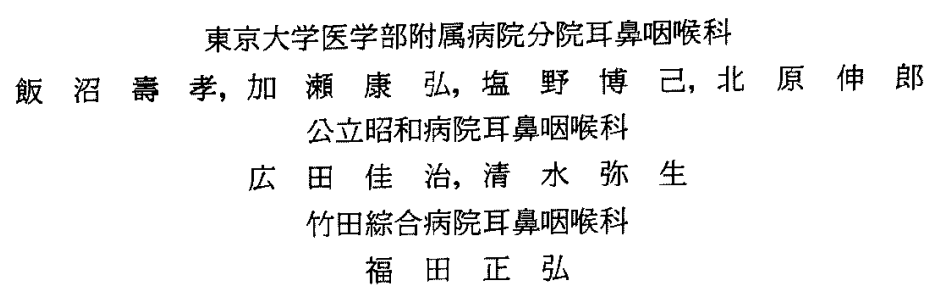

CHILDREN'S SINUSITIS SEEN BY WATERS' VIEW
TOSHITAKA IINUMA, M.D., YASUHIRO KASE, M.D., HIROMI SHIONO, M.D., NOBUO KITAHARA, M.D., YOSHIHARU HIROTA, M.D., YAYOI SHIMIZU, M.D. and MASAHIRO FUKUDA, M.D.

\author{
Department of Otolaryngology, Tokyo University Branch Hospital, Tokyo
}

At the out-patient clinic during the years of 1985 and 1986, 179 sets of X-ray films by Waters' view were obtained by pediatric patients with the clinical diagnosis of chronic sinunitis. These films were analyzed as to the angle of positioning by the image, the degree of lesions (slight, moderate mucosal thickenings and diffuse opacity) and the indistinct finding of the bony walls of the maxillary sinus.

When films were prepared with the routine positioning angle of 45 degrees to the OM plane, the angle as evaluated by the images upon the films tends to be excessive in most of the cases especially in small children. By small childen at the age of $3-4$, the positioning angle should be modified and reduced to 20-25 degrees, and the angle is adjusted up to the age of 10 when the routine 45 degrees will be restored. Excessive angle will give rise to the seemingly increased opacity of the maxillary sinus. X-ray findings in children's sinusitis are symmetrical in $70 \%$ of cases. The bony walls the sinus will be increasingly indistinct as the degree of the lesions advances, $16.2 \%$ in the slight, $47.8 \%$ in the moderate and $72.0 \%$ in the severe degrees, respectively.

In the radiological diagnosis of sinusitis in children, when the possibilities of malignancies and complications were clinically excluded, a single Waters' view will be sufficient up to the age of 46 , and Caldwell's view will be added from the age of 7-9. Ultrasonography in A-mode will aid in reducing exposure to $\mathrm{X}$-ray and in follow-up studies.

Key words：小児副鼻腔炎，X線診断 A A1-1358-33136

1 はじめに

小児副鼻腔疾患にとって画像診断，ことに普通X線 診断は補助的診断法としての意義は定まってはいる が, その歴史の長さにもかかわらず実地化は高率では ない。名越1"によって我が国の現況につきなされたア
ンケート調查によれば小児副鼻腔炎に対するX線診断 の利用率は年長児 $71 \%$, 年少児 $36 \%$, 幼児 $10 \%$ でり， $\mathrm{X}$ 線診断の必要性は年長児 $78 \%$ ，年少児 $55 \%$ ，幼児 36 \%である．小児副鼻腔炎におけるX線診断が年少児と 幼児に適応となるかの問題はのちの検討の項で言及す 
るが，X線診断を必要としながらも，実施はその $1 / 2 に$ 満たないことの主要な原因は，X線被曝に対する配慮， X線撮影と読影が困難であること，などである。合併 症や腫瘍の疑いがない小児副鼻腔炎のX線診断でX線 被曝を最少となすには撮影方向を一方向とし，撮影と 読影の困難を軽減するには小児に特有な状況（解剖学 的及び病態の特異性）をX線診断上で解明する必要が ある，本論文では撮影方向はウォータース法の一方向 とし，実際に得られたX線写真を回顧的に撮影条件と 病的所見とから分析して, ウォータース法による小児 副鼻腔炎診断の有用性と限界とを検討した。

\section{II 対象}

昭和59年加ら61年に至る 2 年間に外来を訪れた小児 䁇者で, 主訴, 現病歴, 鼻内所見から慢性副鼻腔炎と 診断し, X線検查を行った179症例（男子125症例, 女
子54症例)のウォータース法によるX線写真を用いた。 年龄分布は最多数を示す $5-6$ 歳を除き各年齢帯に 25 一30症例である(表 1).ウォータース法は卧位により， 使用機種は KXO-1250(ISOA) 型を用い，撮影条件(小 児用として) は管電圧 $65 \mathrm{kvP}$, 管電流 $400 \mathrm{~mA}$, 撮影時 間 $0.08 \mathrm{sec}$, 撮影距離は $100 \mathrm{~cm}$ とした。ウォータース法 における撮影角度は，X線中心線が耳眼面に45度（ド イツ平面ならば30度見当）とし，X線中心線は外後頭 隆起から眼窩下線に向けフィルムに垂直に投影する.

\section{III 方 法}

\section{1. 撮影角度の分析}

X線写真上で錐体上縁が上顎洞底付近に位置するも の (図 1 の 1 と 2 との間) を画像上から見て撮影角度 が適正であるとし，それより頭側(上顈洞底より上方) にある場合を不足とした。また錐体上縁が上顎洞底付

表 1 年齢の分布

\begin{tabular}{|c|c|c|c|c|c|c|c|}
\hline 性 & 別 & $3-4$ & $5-6$ & $7-8$ & $9-10$ & $11-16$ & 全年齢 \\
\hline 男 & 子 & 20 & 46 & 23 & 16 & 20 & 125 \\
\hline \multirow[t]{2}{*}{ 女 } & 子 & 9 & 23 & 8 & 9 & 5 & 54 \\
\hline & 全症例 & 29 & 69 & 31 & 25 & 25 & 179 \\
\hline
\end{tabular}

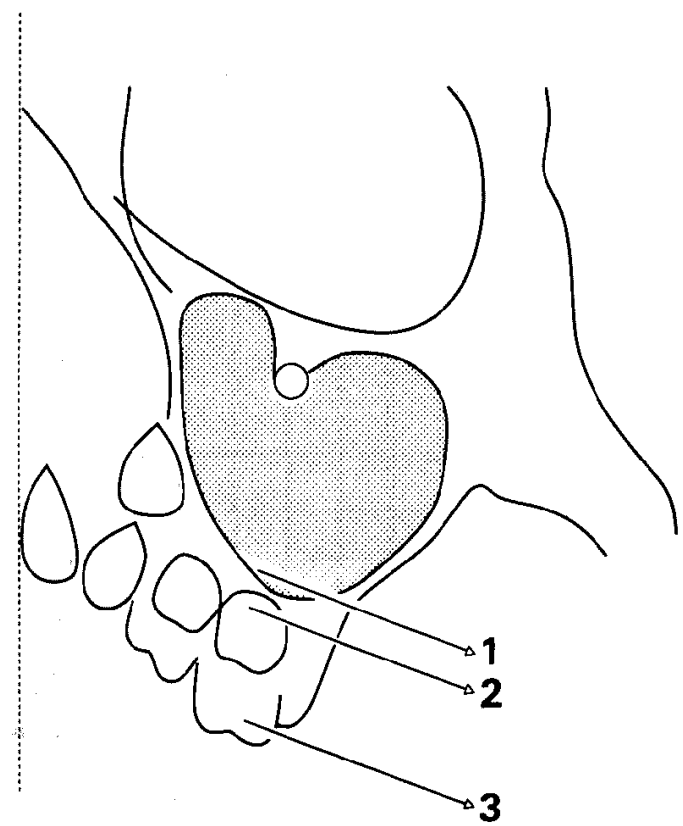

図 1 撮影角度

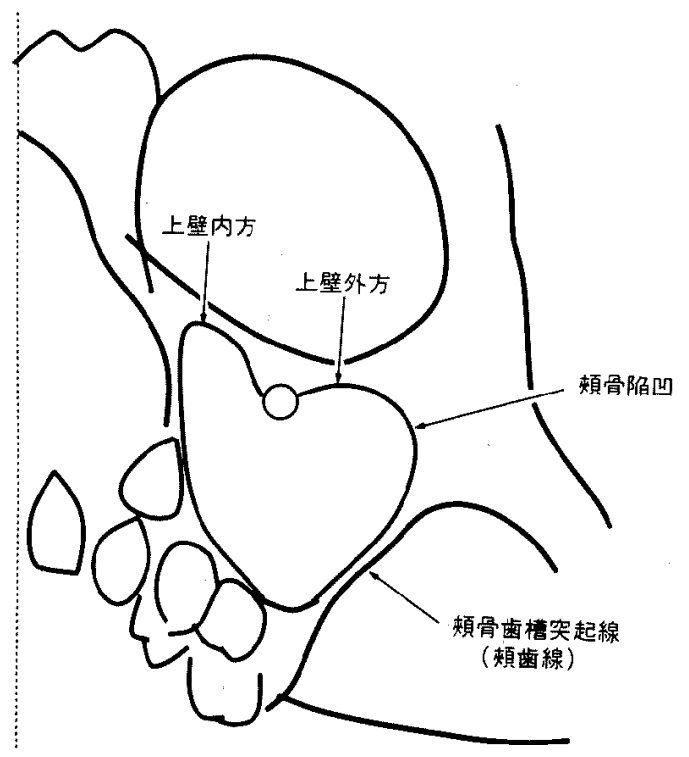

図 2 洞壁の観察部位 
近より尾側で萌出歯牙（主として曰歯）より頭側にあ るもの（図1の 2 と 3 との間）を撮影角度がやや過大 (小過)とし, 萌出雪牙を離れて尾側（図1の3より下 方）にあるものを著しく過大（大過）とした。

\section{2. 病変程度の分析}

$\mathrm{X}$ 線写真上の所見に限った分析であり, 軽度, 中等 度, 高度とした。上顎洞の所見で洞内は含気状態にあ り, 上壁と外側壁（解剖学的には前壁と後壁との移行 部，煩骨歯槽突起線に相当)の平均的な粘膜肥厚が 4$5 \mathrm{~mm}$ 以内のものを軽度とした.上顎洞内がびまん性陰 影増強を示しX線所見で含気がないものを高度とし た. 軽度と高度以外のものを中等度とした。

\section{3. 骨壁の分析}

上枵洞壁の観察部位は上壁, 外側方の壁（前壁と後 壁との移行部で, X線写真上の煩骨菡槽突起線に相 当)，および上顎洞の頓骨楩凹部とした。壁は眼窩下 神経管を境にその内方 (上壁内方) と外方 (上壁外方) とに分割した(図 2)．上罘洞内壁は未萌出歯牙の重複 があるために分析から除外した。

\section{IV 結 果}

1. 撮影角度 (表 2)

すでに方法の項で記したごとくにここに言う撮影
角度とはX線写真上で上蝢洞底部と錐体上緑との相互 関係から判定した画像上の撮影角度があって, 撮影に 際しての中心線と基準面 (耳眼面)との角度ではない。 換言すれば撮影時の角度は規定の通りであっても,こ とに小児の場合は，画像上での錐体上縁の位置は上䫑 洞底をはるかに下方に離饥て，あたかも実際の撮影角 度が過剩であったかの結果を生じやすいことを指す。

表 2 に示すごとくに画像上の撮影角度（以降，撮影 角度と略）が「適正」である率は年齢と共に增加し, 平均 $29.1 \%$ である.「小過」は年路と共にやや減少する 傾向を示し，平均 $38.5 \%$ あ゙ある。また大過」は年龄 と共に減少し, 平均 $25.1 \%$ である.「不足」は年龄を通 して低率で平均 7.3\%である。「小過」と「大過」とを 合計した平均 $63.6 \%$ は小児において過半数が撮影角度 がみかけ上で過剩となることを示す。ことに $3 ー 4$ 蝓 ではその率は93.2\%となる。

\section{2. 病変程度 (表 3 )}

画像上での上顎洞の病変程度は左右各側を 1 単位と して判定し, 表 3 のごとくに6つの組合とし分析した。 例えば「軽一高」とはいずれかの側が軽度病変, その 反対側が高度病変を示したことをいう。「軽一軽」病変 は 3-4 歳と11-16歳との両端の年龄帯に高率である が中間帯は低率である。「軽一中」病変は加齢と共に増

表 2 画像上の撮影角度

\begin{tabular}{|c|c|c|c|c|c|c|}
\hline 角度 & $3-4$ & $5-6$ & $7-8$ & $9-10$ & $11-16$ & 全年齢 \\
\hline 不 足 & 0 & 7.2 & 0 & 16.0 & 16.0 & 7.3 \\
\hline 適 正 & 6.9 & 24.6 & 41.9 & 36.0 & 44.0 & 29.1 \\
\hline 小過 & 48.3 & 37.7 & 41.9 & 28.0 & 36.0 & 38.5 \\
\hline 大 過 & 44.8 & 30.4 & 16.1 & 20.0 & 4.0 & 25.1 \\
\hline
\end{tabular}

(\%)

表 3 病変(左右組み合わせ) と年齢

\begin{tabular}{ccrrrrr}
\hline 年齢 & $3-4$ & $5-6$ & $7-8$ & $9-10$ & $11-16$ & 全年龄 \\
\hline 軽一㪕 & 31.9 & 13.0 & 19.4 & 8.0 & 40.0 & 20.1 \\
軽一中 & 6.9 & 5.8 & 12.9 & 24.0 & 16.0 & 11.2 \\
軽一高 & 0 & 2.9 & 9.7 & 8.0 & 0 & 3.9 \\
中一中 & 20.7 & 24.6 & 22.6 & 44.0 & 8.0 & 24.0 \\
中一高 & 13.8 & 20.3 & 12.9 & 8.0 & 16.0 & 15.6 \\
高一高 & 27.6 & 33.3 & 22.6 & 8.0 & 20.0 & 25.1 \\
\hline
\end{tabular}

(\%), 軽：軽度 中：中等度 高：高度 
表 4 画像上の撮影角度と病変 (左右対称性)

\begin{tabular}{cccc}
\hline 角度 & $\begin{array}{c}\text { 適 } \\
\mathrm{N}: 37\end{array}$ & $\begin{array}{c}\text { 小過 } \\
\mathrm{N}: 37\end{array}$ & $\begin{array}{c}\text { 大過 } \\
\mathrm{N}: 34\end{array}$ \\
\hline 軽一軽 & 32.4 & 28.3 & 26.5 \\
中一中 & 32.4 & 35.8 & 35.3 \\
高一高 & 35.1 & 35.8 & 38.2 \\
\hline
\end{tabular}

(\%)
は撮影角度によらず出現率はほぼ一様となる。

4. 上䪽洞壁所見と年齢（表 5 ）

上額洞壁所見とは骨壁（上顎洞内腔に接する骨膜と 粘膜とが骨壁となる境界線) が不鮮明である所見を指 す．上壁内方は $5-6$ 歳の $21.0 \%$ をピークに山型分布 を示し，全年齢の平均は $18.4 \%$ でる。同じく上壁外 方は 7ー8 歳の $27.4 \%$ を゚ークに $17.3 \%$, 㛲骨楩凹部 は 5-6歳の34.1\%をピークに $24.6 \%$ となる．煩骨雬

表 $\underline{\mathbf{5}}$ _上影洞壁の不鮮明所見と年齢

\begin{tabular}{|c|c|c|c|c|c|c|}
\hline 洞 壁 & $3-4$ & $5-6$ & $7-8$ & $9-10$ & $11-16$ & 全年齢 \\
\hline 上壁内方 & 17.2 & 21.0 & 16.1 & 6.0 & 8.0 & 18.4 \\
\hline 上壁外方 & 13.8 & 18.1 & 27.4 & 22.0 & 16.0 & 17.3 \\
\hline 煩·骨陥凹部 & 25.9 & 34.1 & 19.4 & 14.0 & 12.0 & 24.6 \\
\hline 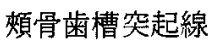 & 0 & 1.5 & 0 & 4.0 & 0 & 1.1 \\
\hline
\end{tabular}

表 6 病変程度と洞壁不鮮明所見の出現率

\begin{tabular}{ccc}
\hline 軽度 & 中等度 & 高度 \\
$\mathrm{N}: 99$ & $\mathrm{~N}: 134$ & $\mathrm{~N}: 125$ \\
\hline 16.2 & 47.8 & 72.0 \\
\hline & & $(\%)$
\end{tabular}

加するがいずれにせよ低率である。「軽一高」病変は全 年齢層を通して低率である.「中一中」病変は $9-10$ 歳 帯にのみ高率である。「中一高」病変は全年齢にほほ均 一に分布する低率である.「高一高」病変は 9-10歳帯 を除き高率であるが $5-6$ 歳以降に隇少する傾向を示 す. 左右がほほ同程度を示す病変を対称性病変, 異な つた程度の組み合わせを示す病変を非対称性病変とす れば, 年齢帯 3-4 歳で対称性病変の率は $79.3 \%$, 以 下同様に 5-6 歳 $(70.9 \%), 7-8$ 歳 $(64.6 \%), 9$ -10 歳 $(60.0 \%), 11-16$ 歳 $(68.0 \%)$, 全年齢 $(69.2$

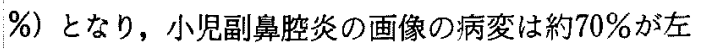
右対称性であって，その傾向は年少児ほど大である。

\section{3. 撮影角度と病変 (表 4 )}

画像上での撮影角度が上䫈洞内のX線透過度にどの ような影響を及ほすのかを知る目的で撮影角度が 「適」,「小過」,「大過」の場合に扔ける左右対称病変 (124 症例)の分布状態を㭘討した。「軽一軽」病変について は「適」から「大過」に移行するにつれて出現率が減 少する傾向を示すが，「中一中」および「高一高」病変
槽突起線は画像上の撮影角度が不足であり，錐体上緑 が重複する場合にのみみられ，平均1.1\%とまれであ る.

\section{5. 病変程度と洞壁所見（表 6)}

上靧洞内のX線透過度 (陰影增強) と上顎洞壁不鮮 明所見との関連を検討する目的で, 洞壁の観察部位の いずれかの部位で洞壁不鮮明な所見が出現する率を病 変程度との関連で㭘討した。軽度, $16.2 \%$, 中等度 47.8 $\%$, 高度 $72.0 \%$ と画像上での病変が高度になるに従っ て洞壁が不鮮明となる率は増加傾向を示す。

$$
\mathrm{V} \text { 検 討 }
$$

1. $\mathrm{X}$ 線撮影法について

副鼻腔X線撮影法には同種異名が多いが，ここでは 後前方向撮影法の内でX線中心線が正中矢状面を通過 し，耳眼面に対して45度をなし，画像上で錐体上縁が 上顎洞底付近でやや下方に位置する方法をウォーター ス法と呼ぶ。同椂に耳眼面に対して20度をなし，錐体 上緑が眼窩底より下方で上顎洞の上部 $1 / 3$ 見当に位置 する方法をコールドウェル法と呼ぶ。合併症や腫瘍の 疑いがない小児副鼻腔炎に扔いてもし一枚のX線写真 で妥当な診断を来すとすれば，その撮影法はウォー夕 一ス法であろう。金子らの研究によれば小児副鼻腔を 問題とする場合にまず上顎洞が主眼となり，次いで斾 骨蜂巣となり, 蝶形骨洞と前頭洞は 2 次的な問題であ

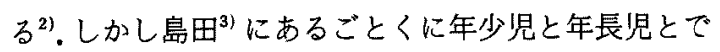


表 7 普通X線所見と鼻鏡所見

\begin{tabular}{lccccc}
\hline 発表者 & 発表年 & 症例数 & 一致率(\%) & \multicolumn{2}{c}{ 不一致率(\%) } \\
& & & & 鏡所見病的 & 鼻鏡所見正常 \\
\hline 倉田
\end{tabular}

は鼻副鼻腔の発育程度や副鼻腔炎の病態に大差があ り，長船(4)の報告にみる小児鼻茸症例は年長児に多発 し副鼻空病変の中心が篩骨蜂巣に移りつつあることを 考慮すると年長児ではウォータース法にコールドウェ ル法を追加することも必要である. 問題は年少児と年 長児との小児副鼻腔炎の予後とも関連し，コールドウ エル法の追加を考慮すべき年齢である．梅沢"゙によれ ば小児副兽腔炎症例を $7-13$ 年間にわたり経過を観察 した結果から，4歳以下では軽度のびまん性カタル型 を示すにすぎないが，4-6歳にいたり限局感染型や 浮腫茸状型が現れて来て病変の程度と病型がやや多彩 となり，この傾向は $7-9$ 歳以降に著明となる. 以上 のごとき小児副鼻腔の発育と小児副鼻腔炎の病態の変 遷とを考慮すれば，4-6歳まではウォータース法の みでよく，7ー9歳以降は，鼻内所見が浮腫咠状型を 呈し管骨病変の X線学的情報が必要とあれば, コール ドウェル法を追加することが妥当となろう。また，長 船6)にあるごとく，小児副鼻腔炎でも12歳以降は手術 適応となり，その術式でも主要なものが鼻内篩骨蜂巣 開放術であるから，手術を前提とする場合にはウォ一 タース法とコールドウェル法の組み合わせが適応とな る.

2. 撮影角度と画像上の病変について

ウォータース法の原著")では頭部の垂直線がフィル ム面におよそ45度をなすとはするものの，これは重視 せず，顔面が凹型では鼻尖をフィルムから $15 \mathrm{~mm}$ 離 し, 凸型では $10 \mathrm{~mm}$ 離すことによって頭顔部形態の個 体差に対応することを強調した。ウォータースの原著 にみるX線写真では錐体上縁は上顎洞底部より頭側 （上方）に位置し，現在の基準からみれば撮影角度は少 な目である.ウォータース法は錐体部を上頻洞から外 す目的で開発された撮影法であるが，錐体部が過度に 外れると画像は半軸位となり，上䫑洞内でX線が通過 する距離が短縮し，上䫑洞内のX線透過度が減少して 見掛け上で陰影增強を来す多. 従ってウォータース法 では錐体上縁が尾側（下方）に下がり過ぎるよりは，
表 8 普通X線所見と手術所見(倉田, ${ }^{11}{ }^{1957)}$

\begin{tabular}{crrr}
\hline X線 & 軽度 & 中等度 & 高度 \\
\hline 軽 度 & 9.5 & 8.8 & 0.7 \\
中等度 & 1.4 & 20.9 & 4.7 \\
高 度 & 0.7 & 23.6 & 29.7 \\
\hline
\end{tabular}

（\%） N:148㑡

表 9 上顎洞穿刺所見との一致率 (Revonta, ${ }^{19}$ 1981)

\begin{tabular}{ccc}
\hline & $\mathrm{X}$ 線所見 & 超音波所見 \\
\hline \multirow{2}{*}{ 貯留液 } \\
\end{tabular}

（\%） N：130，小児

むしろウォータースの原著のごとくに，錐体上縁が多 少は上顎洞底に重複するほうがよい9，実際の撮影角 度が過剰となると上顎洞の下側方（上眼窩裂の下線よ り側方）の部分に淡いびまん性陰影が生ずるが,これ は蝶形骨大翼眼窩面の重複による。

今回の報告では小児におけるウォータース法撮影 が, 実際の撮影角度は基準を守ったものでありながら， 画像上の撮影角度は約 $65 \%$ の症例において過剩てある ことを明らかにした。この傾向は 3-4 歳の幼児に著 しく，過剩である率は約 $90 \%$ に及゙。これは成人を基 準としたウォータース法の撮影角度が小児には不適で あることを示す。このことはすでにマイヤー9が指摘 するところで, 画像でウォータース法の撮影角度（す なわち錐体上縁が上顎洞底の下方付近に位置する角 度）を適正にするには，小児における実際時の撮影角 度は少な目にする必要があり，3-4 歳では耳眼面に 対して20一25度で十分であり，以降，小児の頭部の個 別的発育に合わせて，10歳以降で成人と同じく45度と する. しかし今回の報告で明らかにしたごとく，画像 
上の撮影角度が過剩でもそれによるアーチファクトの 影響を受けるのは軽度病変のみである(表 4). 換言す れば鼻鏡所見などで軽度病変であるものがウォーター ス法の画像上で撮影角度が過剩であり，しかも比較的 淡いびまん性陰影增強を示す場合にはアーチファクト

を敕戒すべきである。

なお，恐怖心の強い幼児では古賀 ${ }^{10)}$ の提唱するごと くにフイルムを後頭部におく逆転ウォータース法がよ いが，画像はやや鮮明を欠き前頭部の上下方向への伸 びによる歪みが強い。

3. ウォータース法の正診率について

はじめに骨破壊と紛らわしい不鮮明な骨壁像(表 5, 表 6)について述べると, 他の臨床所見から総合的に 判定して上顎洞に骨破壊がない症例において，骨壁が 不鮮明となる率は上壁で約20\%, 㛲骨陥凹部で約 $25 \%$ ， 賽骨歯槽突起線で $1 \%$ \%ある.内壁については未萌出 歯牙の重複があり分析の対象から外した。また骨壁が 不鮮明となる率は病変の程度に平行し, 軽度で $16 \%$, 中等度で $50 \%$, 高度で70\%となる.もし左右の病変に 差があればX線診断はより容易となろうが，すでに結 果 2 で述べたごとくに小児副鼻腔炎の画像上の病変は 約70\%において左右対称性を示す，両側性病変の診断 が困難であることはすでに古賀 ${ }^{10)}$ が指摘するところ である.

つぎに小児副鼻腔炎におけるウォータース法による $\mathrm{X}$ 線所見と鼻鏡所見の関係を, 従来の主要な報告の資 料をもとに, 明らかとする. 表 7 の倉田 ${ }^{11)}$, 新谷 ${ }^{12)}$, 毛 利ら ${ }^{13)}$ の資料を平均すると，一致率は約 $80 \%$ である. なお不一致率に関しては鼻鏡所見のみ所見あるもの約 $3 \%, \mathrm{X}$ 線所見のみのもの約 $17 \%$ ある. 広戸ら ${ }^{14)} に$ よれば鼻鏡所見との一致率は, 小学生での直接 X線撮 影法による検診において, 低学年 $59 \%$, 中学生 $70 \%$, 高学年 $73 \%$ ，年齢と共に上昇する。また奥田ら ${ }^{15)}$ は 同様の検診において直接撮影法と間接撮影法とを併用 し，その成績に大差がないとした. 奥田ら ${ }^{15)}$ のデータ でも1636人の検診からX線所見のみのものが約16\%で あった。このように鼻鏡所見が正常でX線所見が異常 なものを我国では潜在性副鼻腔炎と推定する傾向 ${ }^{13) 15}$ にあるが,このような現象の分析によく引用あるショ ップナーら ${ }^{16)}$ の資料では，ウォータース法による小児 X線写真では明らかに副鼻腔が存在しない群, 急性上 気道感染群, それに副鼻腔炎群, 各 100 症例以上の構成 て，X線所見での異常検出率は，それぞれ57，75，51 \%であることから，急性上気道感染群を考慮し診断を
決定すべきであるという。

普通X線所見と手術所見 (小児症例) との一致率は 表 8 のごとくであり，これをまとめるとX線所見の正 診率は $60.1 \%$, 過剩診断 $14.2 \%$, 過小診断 $25.7 \%$ とな る.小児ではなく成人の資料でX線 CT 所見を正診と してウォータース法による上䫑洞所見を検討すると， 正診率 $78.4 \%$, 過剩診断 $21.6 \%$, 過小診断 $1.0 \%$ であ $3^{17}$.

4. ウォータース法と他診断法の関連

対象が小児慢性副鼻腔炎と限れば画像診断の他の診 断法は超音波検査法とX-M.F.T. 法となろう。

超音波検查法についてマン ${ }^{18)}$ は小児副鼻腔炎にお ける正診率は94\%でX線診断にまさり，副鼻腔炎症候 のない小児 $(6-8$ 歳) 59 症例で，いわ沉疑陽性出

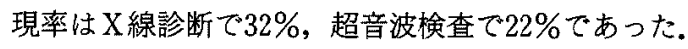
同じくマン ${ }^{18)}$ によれば超音波が人体に有害となる出 力は $0.1 \mathrm{w} / \mathrm{cm}^{2}$ 以上であり，診断用は 0.001-0.004w/ $\mathrm{cm}^{2}$ であることから小児においても無害である.

同じく超音波検直でレボンタら ${ }^{19)}$ の小児副鼻腔炎 130症例で上榞洞穿刺により貯留液つ有無を確定した 資料での一致率は超音波検查で $93.8 \%$ ，普通 $\mathrm{X}$ 線検查 で73.1\%である。これをまとめれば上䫑洞内の貯留液 の有無に関しての超音波検查法の正診率は極めて高率 なので，小児副鼻腔炎の治療経過の観察にはAモード による超音波検査法は有力であり普及してしかる心゙き 方法である。

つぎに小児副鼻腔炎での上顎洞造影法であるX-M.

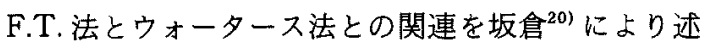
べれば, 両検查法による上顎洞病変とには相関が高く, ウォータース法によっておおむ好正確に評価しうる。 さらに増田ら ${ }^{21)}$ の-M.F.T. 法とマイクロデンシト メータ（ウォータース法による）による計測とでは黒 化度測定は X-M.F.T. 法に準ずる正確度を有する.

以上をまとめると単純なるウォータース法による上 顎洞病変の判定の正診率は60-80\%で, 他の検查法に よる結果とよく相関する。

5. X線診断の適応の問題

たと六小児であっても悪性腫瘍や合併症の疑いにお いてはX線診断法は適応である。明らかな副鼻空炎に おいては適応には様々な条件が付帯する．患児側の問 題は，1）副鼻腔の発育，2）副鼻腔炎病態多様化の時 期，3）患児のきき分けのよさ，でありこれらを総 合すると 4-5 歳以降が適応である。つぎはX線診断 の施行時期の問題で，1）治療方針決定時（治療開始 
時)，2）治療経過中（臨床像混乱, 難治性)，3）治療 終了時(効果判定), がその時期である. 現時点では時 期についての大方の意見の一致をみることは困難であ ろうが, 我々の意見では治療開始時に鼻内所見と既往 歴を参照の上で必要に応じX線診断を行うこととし, 経過は鼻内所見と患児の訴え，あるいは出来れば $\mathrm{A} モ$ ード超音波検查法で上靧洞内に空気が入り得たかどう かを判定し観察するのが無難な方針かと考える，撮影 方向についてはすでにのべたごとくに，4-6歳まで はウォータース法のみ，7ー9歳以降ではこれにコー ルドウェル法を併用することを旨とする。従来から小 児副鼻腔炎のX線診断に関しは消極的意見も数多くあ ったが, それは $3-5$ 歳の幼小児に目立つ困難さを危 惧する慎重さの反映であって, 小児副鼻腔炎全年齢に

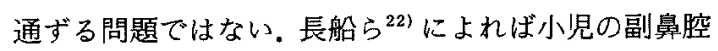
X線写真はデリケートな部分に限れば成人や老人より も読影しやすいというが我々も同感である。

\section{5. 小児副鼻腔炎の変遷と画像診断}

荒有 ${ }^{23)}$ による国立小児病院の調查では外来患者総 数に対する比率を昭和 44 年と昭和 53 年とで比較検討す ると副鼻腔炎は $50 \%$ から $20 \%$ に, 鼻アレルギーは $5 \%$

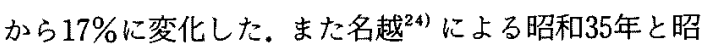
和53年における小児副鼻腔炎の受診年齢分布を比較す ると，3-5 歳児の分布は $8.7 \%$ から $36.1 \%$ に $12-14$ 歳児の分布が $21.0 \%$ から $11.4 \%$ に変化し, 受診年齢が 学童期から幼小児期に移行した。 また川名ら ${ }^{25)}$ の学校 健診に扔ける昭和 45 年と昭和 53 年の有効率は鼻炎が $17.2 \%$ から $11.9 \%$ に, 副鼻腔炎が1.5\%から0.6\%に変 化した。

荒木 ${ }^{23)}$ によれば病態の軽症化は幼児と低学年に顕 著であるが，高学年児では依然として高度病変を有す るものの比率は高く難治性であるという. 名越 ${ }^{24)} に よ$ れば臨床病型の昭和 42 年と昭和 53 年との比較では限局 感染型が23.1\%から15.2\%に,びまん・カタル型が65.4 \%から $78.7 \%$, 浮腫茸状型が11.5\%から6.1\%に変化 した.ただこの病型の変化には幼小児の増加が関与 し,びまん・カタル型が増加したのである。昭和 53 年 の $3-5$ 歳と 12 - 14 歳とでの浮腫茸状型の比率は $1 \%$ と $20 \%$ となり, 年長児では難治性高度病変の占める率 は依然として高率である。

以上をまとめれば小児副鼻腔炎は小児耳鼻咽喉科疾 患の中での比率が低下しつつあり，受診年齢が低下す ると共に病型としては軽症で自然治瘱傾向の強いびま ん・カタル型の占める率が上昇した，従って画像診断，
ことにX線診断を行う機会は減少しより受診年齢の

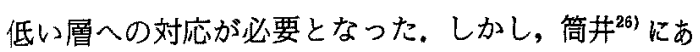
るごとく, 病理組織学的にみての小児副鼻控炎は本質 的に成人のそれとは異ならないが，成人に比較して線 維型が少なく,むしろ早期病変に相当する病像が多い。 また, 肉眼解剖学的にみて, 発育の差はあれ, 含気腔 の基本的形態は小児と成人とでは異ならない. 従って 小児副鼻腔炎の変遷は X線検查の撮影頻度わよび実施 すべき撮影方向の数と組み合わせ（ウォータース法の みか, それとコールドウェル法を組み合わせるか）に は影響を及济すが，X線検查の基本的大筋の変遷を必 要としない.今後の問題はX線診断に超音波診断法を 組み合わせて, より安全でリアルタイムに簡単な検查 手順を開発し普及することである。

\section{$\mathrm{VI}$ ま め}

1. 小坚副鼻腔炎179症例のウォータース法による $\mathrm{X}$ 線写真を対象として, 画像上の撮影角度, 上頻洞の 病変, 上顎洞骨壁の所見を分析した。

2. 撮影夷施時の撮影角度が成人に準じて適正であ っても画像上の撮影角度は過半数において過剩であ り，その傾向は幼少児に強い。

3. 画像上での撮影角度の過剩は軽度病変において 見掛け上での陰影增強を来しうるが中等度以上の病変 の陰影には影響を来さない。

4. 小児副鼻腔炎の画像上での病変は約 $70 \%$ で左有 対称的であり，その傾向は幼小児に強い.

5. 上顎洞壁の不鮮明な所見の出現率は, 上䫑洞上 壁内方で $18.4 \%$, 同外方で $17.3 \%$ ，頓骨陥凹部で 24.6 \%, 頖骨歯槽突起線で1.1\%である。

6.いずれかの部位で洞壁が不鮮明となる率は軽度 病変で $16.2 \%$, 中等度で $47.8 \%$, 高度で $72.0 \%$ となり, 画像上での病変が高度になるに従って洞壁の所見は不 鮮明となる。

7. 小児におけるウォータース法では，成人に扔河 る撮影角度 (耳眼面に対して45度) を修正し， 3-4 歳では20-25度とし，以降は年㱓と小児の個体として の発育に合わせて，10歳以降ではじめて成人なみとす る.

8. 小览副鼻腔炎の $\mathrm{X}$ 線診断では，合併症や悪性腫 瘍の疑いがない場合は，4-6歳まではウォータース 法のみでもよく，7-9 歳以降は症例に応じてコール ドウェル法を併用する。

9. 他の画像猃断として, 上頇洞内の眝留液の有無 
に関してはAモード超音波検查法が有用である。

10. 小児副鼻腔炎の画像診断にはX線診断法に超音 波診断法を組み合わせることで経過観察と治療効果の 判定がより簡単となろう。

\section{文献}

1）名越好古：小児慢性副鼻腔炎の病態と治療，宿題報告 別刷, 93-94頁, 1960 .

2）金子善一,萩尾千和：小児副鼻腔のレ線撮影法の検討, (その1)頭位と撮影条件の問題について.日耳鼻 60 ： 1128-1132, 1957.

3）島田和哉：学童検診よりみた小児副鼻腔炎の変遷.耳 犊 $52: 545-552,1980$.

4）長船宏隆：小児の鼻茸について.耳鼻 26:645-648, 1980.

5）梅沢美和子：小児期鼻副㐭腔の予後に関する研究．耳 展 17 (補 1)：5-23，1974.

6）長船宏隆：小児慢性副鼻腔炎の治療について，耳鼻 $27: 127-130,1981$.

7) Waters CA : Roentgenology of the accessory nasal sinuses describing a modification of the occipitofrontal position. Amer J Roentgenol 2 : 633-639, 1915.

8) Samuel E \& Lloyd GAS : Clinical radiology of the Ear, Nose and Throat, 2nd Ed., pp. 1-3, Saunders, Philadelphia, 1978.

9) Mayer EG: Diagnose und Differentialdiagnose in der Schaedelroentgenologie, S. 12, Springer, Wien, 1959.

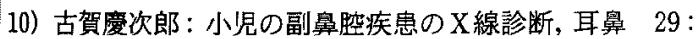
973-975, 1983.

11）倉田 寛：小児慢性副鼻腔炎のレ線学的研究, 第 2 篇, 単純撮影法の検討. 日耳鼻 $60: 423-432 ， 1957$.

12）新谷公章：小児副鼻腔の集団間接撮影について. 北海 道医誌 35：400-409，1960.

13）毛利 学 他：小児慢性副鼻腔炎X線診断の反省. 耳鼻
䙔床 $72: 1219-1228,1979$.

14）広戸幾一郎 他：副鼻腔間接レ線撮影法による学童検 診成績について。耳鼻臨床 54：19-23，1961。

15）奥田 稔 他：鼻粘膜炎症と体質をめぐる問題，(その 5 ) 慢性副鼻腔炎の疫学的研究と集団検診法の検討. 耳 喉 $37: 221-229,1965$.

16) Shopfner CE et al: Roentgen evaluation of the paranasal sinuses in children. Amer J Roent. genolog 112 : 176-186, 1973.

17）飯沼寿孝：臨床医からみた画像診断. 臨放 $32 ： 606-$ $609,1987$.

18) Mann WJ : Ultraschall im Kopf-Hals-Bereich, S. 7, 32, Springer, Berlin, 1984.

19) Revonta $M$ et al: Diagnosis of subacute sinusitis in children. J Laryngol 95: 133-140, 1981.

20）坂含康夫：小呪の副鼻腔炎. JOHNS $3: 1039-1045$ 1987.

21）増田佐和子 他：マイクロデンシトメーターによる小 罗慢性副鼻腔炎．上顎洞の黒化度測定と治療効果の判 定. 耳喉 59:641-645，1987.

22）長船宏隆ら：小児副鼻整炎のレ線学的診断について 耳展 23:43-53， 1980 .

23）荒木昭夫：日本の舅疾患の現状と将来 (その2) 小児鼻 疾患の現状と将来。耳展 22:201-206，1979。

24）名越好古：小児副鼻腔炎の変要と対策. 耳喉 $52: 539$ $-544,1980$.

25）川名正二他：学校健診における耳鼻咽喉科疾病像の 変化について. 耳展 $23: 573-579 ， 1980$.

26）筒井邦雄：小児慢性副鼻腔炎に関する襙床的研究．耳 鼻 4 (補 2 ) : 107-126, 1957.

本稿の要旨は第 1 回日耳鼻専門医講習会で発表した。

（原稿受付 昭和62.12.2日）

別刷請求先 $\overline{1} 112$ 東京都文京区目白台3-28-6 東京大学医学部附属病院分院耳亶咽喉科 飯沼壽孝 